UDC $613.1 ; 614.7$

DOI: $10.21668 /$ health.risk/2017.2.08.eng

\title{
TRIAL HYGIENIC ASSESSMENT AND MINIMIZING ENVIRONMENTAL HEALTH RISKS DURING LEADERS COUNCIL MEETING OF SHANGHAI COOPERATION ORGANIZATION COUNTRIES AND MEETING OF LEADERS AND GOVERNMENT HEADS OF BRICS COUNTRIES HELD IN UFA
}

\author{
S.V. Kleyn ${ }^{1,2}$, S.Yu. Balashov ${ }^{1}$, E.G. Stepanov ${ }^{3}$, N.Kh. Davletnurov ${ }^{3}$ \\ ${ }^{1}$ Federal Scientific Center for Medical and Preventive Health Risk Management Technologies, \\ 82 Monastyrskaya Str., Perm, 614045, Russian Federation \\ ${ }^{2}$ Perm State National Research University, 15 Bukireva Str., Perm, 614990, Russian Federation \\ ${ }^{3}$ Federal Service for Surceillance over Consumer Rights protection and Human Well-being, Bashkortostan \\ Republic regional office 58 R. Zorge Str., Ufa, 450054, Russian Federation
}

\begin{abstract}
The article outlines the results and experience obtained in the process of giving scientific grounds for volume and essence of a monitoring program, and detecting territories with health risks for Ufa city population, as well as for participants and visitors during the Summits (SCO member states leaders council and meeting of BRICS leaders and heads of BRICS countries governments). We detected that if unfavorable meteorological conditions occurred (calm or wind weaker than $0.5 \mathrm{~m} / \mathrm{sec}$ ) and if industrial enterprises were working at full capacity together with motorways being under peak loads it could lead to unacceptable health risks in areas where the Summits were organized; such risks for exposed population were related to dangers for respiratory organs ( up to 5.66HI), eyes (up to 3.2HI), and system effects (up to 1.3HI). When we modeled weather conditions which were typical for July risks were assessed as being lower (in relation to respiratory organs up to 2.8HI, eyesight, up to 1.05HI, system effects up to 1.03HI), and an area where such risks could possibly occur was considerably smaller. We didn't detect any unacceptable health risks for participants and visitors of the Summits under exposure to chemical admixtures from drinking water and soil $\left(H I=0.17\right.$ and $H I=3.95 * 10^{-7}$ correspondingly). We suggested optimal programs for monitoring environmental objects aimed at providing maximum control over the situation. We also recommended to perform additional measurements of PM10 and PM2.5 fine-dispersed dust fractions when monitoring air quality. A comprehensive sanitary analysis of drinking water and soil quality control as per standard programs were offered. We created a set of activities which allowed to minimize health risks and to provide safe conditions for the Summits in term of all the examined factors. Implementation of the created monitoring program and recommended sanitary-epidemiologic activities as per data of instrumental air quality examination (more than 40,000 examinations as per 30 admixtures) as well as drinking water and soils during the SCO and BRICS Summits and on the days when the delegations arrived and left allowed to eliminate unacceptable risks for negative impacts on the health of Ufa population, participants, and visitors of the Summits. Participants and visitors of the events didn't suffer from any acute health disorders during this period.

Key words: public and political activities, safety, international legal regulation, environmental factors, population health provision, health risk.
\end{abstract}

Preparing for and holding mass public and political events of an international level in the Russian Federation territory requires signifi- cant efforts. Rospotrebnadzor and other agencies are responsible for ensuring sanitary and epidemiological welfare, and protection from

(C) Kleyn S.V., Balashov S.Yu., Stepanov E.G., Davletnurov N.Kh., 2017

Svetlana V. Kleyn - Candidate of Medical Science, Associate Professor of Human Ecology and Life Safety (e-mail: kleyn@fcrisk.ru; tel.: +7 (342) 237-18-04).

Stanislav Yu. Balashov - head of the complex sanitary-hygienic analysis and examinations techniques laboratory (e-mail: stas@fcrisk.ru; tel.: +7 (342) 237-18-04).

Evgenii G. Stepanov - Candidate of Medical Science, Head (e-mail: Stepanov_EG@02.rospotrebnadzor.ru, tel.: +7 (347) 229-90-99).

Nail Kh. Davletnurov - Head of social-hygienic monitoring department (e-mail: Davletnurov_NKh@02.rospotrebnadzor.ru, tel.: +7 (347) 229-90-50) 
biological and chemical threats, in particular, at planning and scoping areas of preventive focus. According to global and national experience, the scientific grounds and phased strategy for practical implementation of sanitary and epidemiological measures aimed at health security of the population, participants and guests at public and political events are the conditions of priority in ensuring sanitary and epidemiological well-being in a region of events. Security in holding such events at the international level is a kind of an indicator showing the development of a country that holds such events.

According to the WHO Secretariat Report "Global mass gatherings: implication and opportunities for global health security" "... planning and preparedness for mass gatherings includes specific public health measures developed in advance of the event ..." and "... an allhazard approach to public health risks is generally recommended by WHO" [3].

Organizers of major international events, including sports (Olympic Games, Universiades, world championships, etc.), at the preparation stage, are trying to identify and minimize all risks to the health of events participants and guests $[5,9,15,16,18,20]$. At the same time, all risks associated with terrorism and biological threats are under special control at all mass gatherings [1, 3, 13, 14], and are an integral part of the national security system of each state.

At the same time, when organizing social and political events at the international level, it is extremely important to take into account international legal regulation of the right to protect health, freedom and other globally recognized human rights, which imposes the obligation on the state (the host party) to use mechanisms ensuring these rights. In some cases, special general "standards of quality, control and coordination of the participating countries actions" are developed, in other cases the event is organized in accordance with the international medical and sanitary regulations, current legislation of the host state, including the regulatory standards for habitat quality aspects [5].
Reviewing global experience in organizing and holding mass international events showed that in Athens (2004), as for environmental objects, only the quality of drinking water was monitored; in Beijing (2008), in addition to a comprehensive systematic analysis of drinking water, systematic sampling and analysis of atmospheric air samples for sulfur dioxide, fine dust $\left(\mathrm{PM}_{10}\right)$, nitrogen dioxide, carbon monoxide was carried out. In preparation for the XXVII World Summer Universiade in Kazan in 2013, the XXII Winter Olympic Games in Sochi, in 2014, in Russian Federation, as well as within the framework of the present study, preparation for the Council meeting of the States Leaders of Shanghai Cooperation Organization and the meeting of the Heads of BRICS States and Governments in 2015, in Ufa (hereinafter, SCO and BRICS Summits), an attempt was made to assess risks of developing negative responses in relation to health of people, visitors and participants in activities caused by chemicals, with the goal to timely minimize them and arrange an effective control during the period of events $[2,4,6,8$, $10,11,19]$.

Research work on scoping the risk areas for the health of guests and participants in summits, rationale for selection of priority chemical pollutants of habitat, subject to sanitary and epidemiological control in places of public and political events of the international level in Ufa was carried out according to the statement of the Federal Service for Surveillance on Consumers Rights Protection and Human Wellbeing in the Republic of Bashkortostan, No. 02-12-20270, ddt. December 15, 2014.

The purpose of the study was to assess risks for developing negative responses due to the effects of chemicals on the part of the health of population, participants and guests on summits, prioritizing chemical impurities to be systematically monitored in the ambient air, drinking water and soils, and working out measures to minimize health risks to the events participants.

Materials and methods. Ufa city is the administrative center of Bashkortostan Repub- 
lic, an important federal transport hub, large industrial center with a high traffic load. In Ufa, there are 163 large and medium-sized enterprises of various property types, of different economic activities, including enterprises of fuel and energy and machine-building complexes, chemical, timber, woodworking, construction and other industries are concentrated.

According to the study purpose, the objects thereof were: Ufa city territory, the quality of atmospheric air, drinking water and soils, the risks to public health under the influence of chemical factors of environmental pollution during SCO and BRICS Summits.

Based on the regulatory documents in force in Russian Federation that specify environmental factors quality and duration of activities, the priority chemicals were selected according to an assessment of compliance with the hygienic standards for air, drinking water and soil quality, as well as according to the risks assessment of an acute health effects. We considered the criteria and recommendations of the global methodology ("Guidelines for assessing human health risks from environmental hazards") and national harmonized documents.

Within the framework of the present study, the following provisions and assumptions were taken into account for exposure assessment:

- Chemical composition of the atmospheric air (outdoor air) determines chemical composition of the air inside the objects of summits (indoors);

- The Summits duration (3 days) is not critical for the formation of chronic health effects on the events' participants and guests, and determines relevancy of applying criteria for acute harmful effects of chemical nature on humans;

- Unfavorable weather conditions (surface inversion, windless condition, weak dispersion of discharges from enterprises and vehicles) were taken into account in this study;

- During the events (Summits), using water from the centralized drinking water supply system for drinking purposes without additional special devices and cleaning reagents may create extra health risk;

- During Summits, economic entities that provide their operation will function in a regular mode (the study did not take into account any extraordinary and emergency situations).

The assessment of compliance with hygienic standards and risk assessment were carried out in a targeted manner for locations of official events and for the objects of accommodation, catering, medical services for summits' participants and guests at SCO and BRICS Summits (2015) (Figure 1).

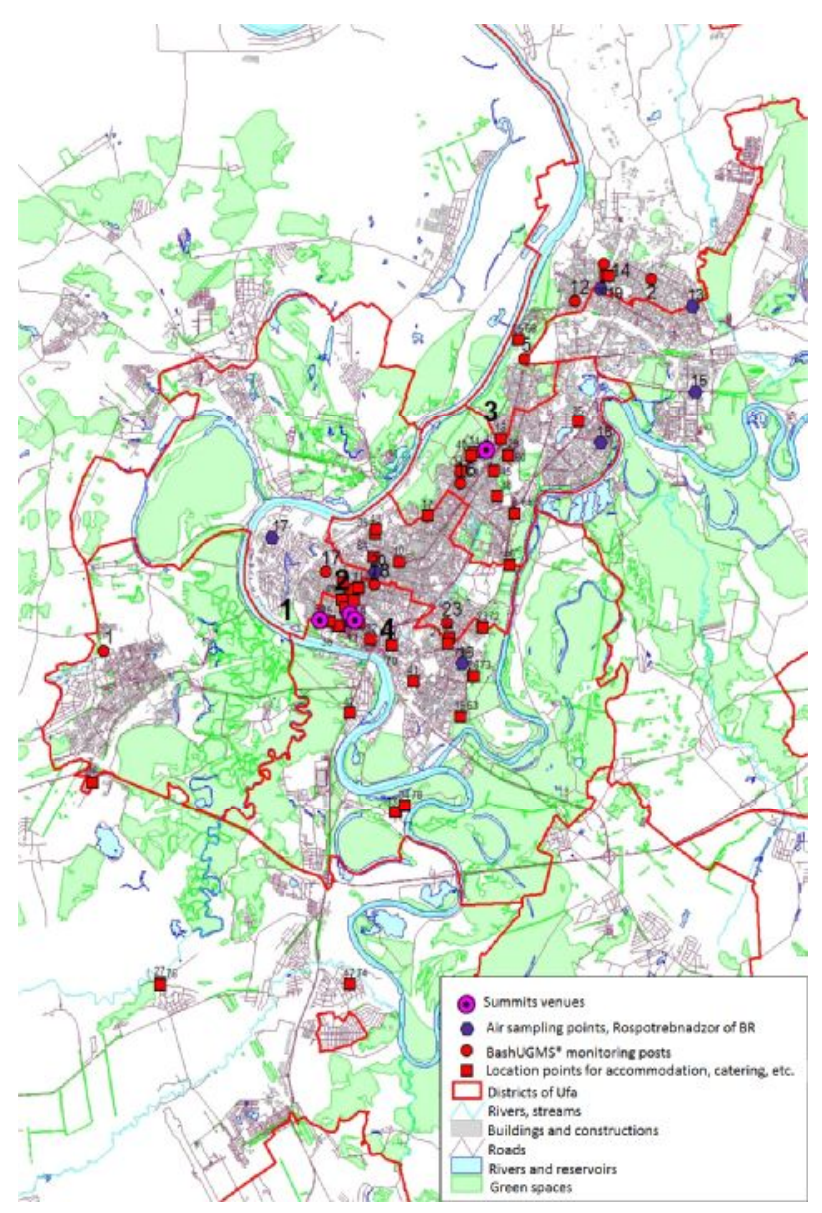

* Bashkir Department for Hydrometeorology and Environmental Monitoring

Fig. 1. Location of facilities for official events, accommodation, catering, medical services for participants and guests on Summits in Ufa, observation posts and air quality monitoring points 
In addressing problems, we used approaches of international methodology and criteria for risk assessment [12, 17], taking into account effects of chemicals contained in the atmospheric air, drinking water and soil.

To identify the priority admixtures, the atmospheric air pollution level was assessed on the basis of instrumental data at 9 monitoring stations of the Bashkir Hydrometeorology and Environmental Monitoring Center, and 8 monitoring points of the Center for Hygiene and Epidemiology in the Republic of Bashkortostan (2009-2014); and the simulation results of impurities dispersion (more than 55 thousand points) were also taken into account.

In view of the dominating long-term annual average wind rose with the prevalence of south-south-west winds and the location of six major industrial enterprises of the city, which account for about $80 \%$ of all discharges from the stationary sources in Ufa city, at a considerable distance to the northeast, we carried out an inventory of the mobile air pollution sources at Ufa' main transport highways. The distance from the Summits venues to the largest industrial enterprises was $8864.7-24539.2$ $\mathrm{km}$.

The forecast estimate was based on the dispersion of impurities in the ambient air following the consolidated available database on the sections of the roads network, which were considered as the sources of emissions from the motor vehicles (238 city main highways sections with a total length of $285,244 \mathrm{~km}$ and an intensity of between 2,000 and 140,000 cars per day). Calculating the dispersion of pollutants allowed for the most accurate assessment for the distribution of air pollution by motor vehicle emissions as the main source of adverse effects on the atmospheric air during summits.

Calculations for dispersion were done using UPAPE (Unified Program of air pollution estimation) "Ecolog-City 3.0" with the construction registration block and the block for calculating the average annual concentrations (Developer - Company Integral, St. Peters- burg) for the worst meteorological conditions (absence of wind, low dispersion of impurities in the atmosphere) in summer time, as well as for meteorological parameters typical for the time of the Summits (July, north-west wind at a speed of $2.7 \mathrm{~m} / \mathrm{s}$ for Ufa). In total, 9 chemical substances were considered for the initial calculations, i.e. the components of urban vehicle emissions.

The concentrations of pollutants were determined at the grid points (more than 55,000 points) of the calculating rectangle, which area covered almost the entire city (calculation site coordinates: $\mathrm{X} 1=-6995.90 ; \mathrm{Y} 1=6093$ 844.63; X2 = 30 804.10; Y2 = 6039 044.63, width $Z=54,800 \mathrm{~m}$, step along $X$ axis $=200 \mathrm{~m}$, $\mathrm{Y}$ axis $=200 \mathrm{~m}$. In addition, calculations were carried out at 81 points, which were the geometric centers for the objects of summits' official events, catering, medical care for summits participants and guests.

The calculations results were verified with the field survey data from the state posts and air quality monitoring points ${ }^{1}$.

The risk assessment of acute inhalation effects was carried out in accordance with the algorithm, criteria and recommendations $P$. 2.1.10.1920-04 "Guidelines for assessment of risk to public health when exposed to chemicals that pollute environment" [12]. The risk at each calculation point was expressed through hazard ratios and indices (HQ and HI, respectively), assuming that coefficients and hazard

indexes values over a unit are the evidence of an increased risk to health of the exposed people.

The contribution of each chemical to the risk of health disorders was determined in the grid points, at the locations of event facilities, accommodation of the Summits' participants and guests.

Assessment of exposure to water factor was carried out according to the data of the Federal Budgetary Healthcare Institution "Center for Hygiene and Epidemiology in the Republic of Bashkortostan" (12 monitoring

\footnotetext{
${ }^{1}$ Territorial zoning method in terms of risk level to the population health under conditions of exposure to chemically hazardous substances: Patent for Invention RUS 2441600 ddt. 31.08.2010/Zaitzeva N.V., May I.V., Klein S.V., Vekovshinina S.A., Balashov S. Yu. - M., 2010.
} 
points) and the Central Chemical and Bacteriological Laboratory of Municipal Unitary Enterprise "Ufavodokanal" (2012-2014). The soil quality assessment was done according to the monitoring data of the Federal Budgetary Healthcare Institution "Center for Hygiene and Epidemiology in the Republic of Bashkortostan" in 8 locations (2013-2014). Assessment of health risks from exposure to chemical factors of drinking water and soil was performed based on the data of the instrumental studies with relevant recording [12].

As the priority admixtures, we identified those impurities for which incompliance with the hygienic standards was forecasted and/ or which most significantly contributed to the formation of acute health risks at the events locations. Using the results obtained, the risk assessments comprised a list of priority chemicals subject to sanitary and epidemiological control, and also formed the proposals for arranging the additional monitoring points and measures to minimize health risks.

Results and discussion. According to the report of the Ministry of Natural Resources, Republic of Bashkortostan, in the recent years, more than 100 kinds of chemical substances with a total mass exceeding 200 thousand tons of pollutants have been emitted into the city's atmospheric air. In 2014, compared to the previous year, insignificant growth of emissions into the air from the stationary sources was registered: by $1.1 \%$ (148.2 thousand tons). The structure of emissions from stationary sources in 2014 was dominated by volatile organic compounds: $59.2 \%$, sulfur dioxide: $16.5 \%$, nitrogen oxides: 9.1\%, carbon monoxide: $5.4 \%$.

The share of industrial emissions in the total pollution, in 2009-2012, made about 35$48 \%$, in $2013-64 \%$. The major contribution to the emissions from the stationary sources in 2013 was made by the enterprises of oil refining industry $(77.2 \%)$ and electric power (4.3\%). The pollutants spectrum entering the air from enterprises is considerable. Among the impurities that deteriorate the air quality in the city, there were substances of the first and second hazard categories (chromium, benzene, phenol, acrolein, formaldehyde) and substances with a low irritant threshold (hydrogen sulphide, etc.). More than $77.2 \%$ of all emissions from the stationary sources were formed by JSC "ANK "Bashneft"", a branch of BashneftUNPZ, JSC "ANK "Bashneft"", a branch of Bashneft-Novoil, and JSC "ANK "Bashneft"", a branch of "Bashneft-Ufaneftekhim", about 2.6\%: OJSC" Ufaorgsintez ", located at a significant distance from the north-east of the city center and from the location of the Summits objects.

According to observations of the air basin status carried out by the Bashkir Hydrometeorology and Environmental Monitoring, in 2013, the air pollution level in Ufa was 9, and was characterized as "high". The averageannual concentrations exceeded the maximum permissible levels: 3.3 times for formaldehyde, 1.5 times for benzenpyrene, and 1.2 times for nitrogen dioxide.

During 2013-2014, in Ufa, there were recorded cases of excess in $\mathrm{MPC}_{\text {single max }}$ for hydrogen sulfide: up to $13.3 \mathrm{MPC}$, for nitrogen dioxide: up to $10.8 \mathrm{MPC}$, ethylbenzene: up to 9.5 MAC, suspended substances: up to 6.2 MPC, hydrogen chloride: up to 5.1 MPC, nitrogen oxide: up to 4.4 MPC, benzpyrene: up to 5.8 MPC, carbon oxide: up to 2.6 MPC, xylenes: up to 4.5 MAC, phenol: up to 3.7 MPC, formaldehyde: up to $2.0 \mathrm{MPC}$.

Specific weight of atmospheric air samples exceeding maximum permissible concentrations, in Ufa, \%

\begin{tabular}{|c|c|c|c|c|c|c|c|c|}
\hline \multirow{2}{*}{ Territory } & \multicolumn{2}{|c|}{$\begin{array}{c}\text { Total } \\
\text { exceeds }\end{array}$} & \multicolumn{4}{|c|}{ Excess coefficient } \\
\cline { 2 - 9 } & 2011 & 2013 & 2011 & 2013 & 2011 & 2013 & 2011 & 2013 \\
\cline { 2 - 10 } & 0,9 & 1,02 & 0,7 & 0,67 & 0,2 & 0,24 & 0,05 & 0,07 \\
\hline Ufa city & &
\end{tabular}


According to the Federal Budgetary Healthcare Institution "Center for Hygiene and Epidemiology in the Republic of Bashkortostan", in 2013-2014, Ufa city monitoring posts recorded the exceedences in hydrochloride (up to $2.0 \mathrm{MPC}_{\text {single max }}$ ), in carbon oxide (up to 2.8 $\mathrm{MPC}_{\text {single max }}$ ), suspended substances (up to 1.6 $\mathrm{MPC}_{\text {single max }}$ ), dimethylbenzene (up to 3.9 $\mathrm{MPC}_{\text {single }}$ max), ethenylbenzene (up to 2 $\mathrm{MPC}_{\text {single max }}$ ), lead (up to $1.3 \mathrm{MPC}_{\text {single max }}$ ), etc.

Generally, in Ufa, in 2013, according to the state report "On the status of sanitary and epidemiological well-being in the Republic of Bashkortostan in 2013", $1.02 \%$ of samples with excess in MPC were recorded (table). At the same time, an exceeding the hygienic standards of up to 2.0 MPC was detected for formaldehyde; up to 5.0 MPC - for ethenylbenzene, hydroxybenzene, carbon oxide; for 6 substances (ethylbenzene, dihydrosulphide, dimethylbenzene, nitrogen oxides, suspended substances, hydrochloride) - over 5 MPC.

In 2014, according to the data of the Federal Budgetary Healthcare Institution "Center for Hygiene and Epidemiology in the Republic of Bashkortostan", at the atmospheric air quality monitoring points in the city of Ufa, the following excesses were registered: for nitrogen dioxide (up to $3.3 \mathrm{MPC}_{\text {single max }}$ ), dihydrosulfide (up to $1.1 \mathrm{MPC}_{\text {single max }}$ ), lead (up to $1.2 \mathrm{MPC}_{\text {single max }}$ ), hydrochloride (up to 1.2 $\mathrm{MPC}_{\text {single max }}$ ), carbon oxide (up to $1.7 \mathrm{MPC}_{\text {sin- }}$ gle $\max$ ), suspended substances (up to 1.2 $\mathrm{MPC}_{\text {single max }}$ ), gasoline oil (up to $1.1 \mathrm{MPC}_{\text {single }}$ $\max$ ), formaldehyde (up to $1.1 \mathrm{MPC}_{\text {single max }}$ ), dimethylbenzenes (up to $1.8 \mathrm{MPC}_{\text {single max }}$ ), ethenylbenzene (up to $2.7 \mathrm{MPC}_{\text {single } \max }$ ), methylbenzene (up to $1.5 \mathrm{MPC}_{\text {single }} \max$ ), ethylbenzene (up to $4.4 \mathrm{MPC}_{\text {single max }}$ ).

As per analysis of the drinking water supply parameters, the main source for the water supply in Ufa is 'Ufa' river (for the Demsk water intake - the river Belaya). The Ufa River serves as a direct source for an open river intake facility (the water treatment facilities of the Northern Water Supply Complex), and by $80 \%$ conditions the quality of the underground infiltration waters intakes (of the Southern city water intake, the $2^{\text {nd }}$ upstream infiltration water intake of the Northern Water Supply Complex, the Shakshinsky Water Pipeline of the Northern Water Supply Complex, Izyaksky water intake, "Cooperativnaya Plyana" water intake).

According to the "State report on the natural resources and the environment of the Republic of Bashkortostan in 2013," the water quality in the river Belaya within Ufa city, the Ufa River (Ufa city) changed by 1 class, having passed from the $4^{\text {th }}$ class of "dirty" category to the $3^{\text {rd }}$ one of "very polluted". Among the significant indicators of water pollution in the Ufa and Belaya rivers near Ufa city are manganese, iron, copper, sulphates, phenol, and oil products.

According to the Central chemical and bacteriological laboratory of the Municipal Unitary Enterprise "Ufavodokanal" in 2013, 159,089 water samples in total were examined $(157,100$ - in $2012 ; 151,518$ - in 2011) for sanitary and chemical parameters; 66 samples $(0.04 \%)$ of them did not meet hygienic standards (in 2012: 25 (0.02\%), in 2011: 75 $(0.04 \%)$ ); and among 17,619 samples (in 2012: 17,063, in 2011: 14,663) tested for microbiological parameters, 50 samples or $0.3 \%$ (in $2012-65$ or $0.4 \%$; in $2011-85$ or $0.5 \%$ ) did not meet hygienic standards. In 2014, the Central chemical and bacteriological laboratory of the Municipal Unitary Enterprise "Ufavodokanal" totaled 151,252 water samples for sanitary and chemical parameters, and 13,216 samples - for microbiological parameters, 7 or $0.05 \%$ of which did not conform to hygienic standards.

The research of the Federal Budgetary Healthcare Institution "Center for Hygiene and Epidemiology in the Republic of Bashkortostan" in 2013 showed that $15.6 \%$ of the samples did not meet hygienic standards as per sanitary and chemical parameters (turbidity, color, and iron content), and $1.7 \%$ - as per microbiological ones.

According to the socio-hygienic monitoring, summarizing 12 monitoring points data for the drinking water samples in the city dis- 
tricts, including the water intakes "Yuzhny", "Cooperativnaya Plyana", "Severniy", "Demskiy", "Izyakskiy", "Shakshinskiy", "Severniy Kovshoviy", and 5 water supply networks, for 2013-2014, the exceedences were registered for iron - up to 1.4 MPC, nitrates - up to 1.2 MPC, manganese - up to 6.6 MPC. As per microbiological parameters, no exceeding in hygienic standards was recorded.

According to the soil data studied for compliance with the requirements of SanPiN 2.1.7.1287-03 "Sanitary and epidemiological requirements for soil quality", in Ufa, in 2013, an exceedance of the hygienic standards for sanitary and chemical indices was detected in 4 samples (zinc, nickel in concentrations of up to $2 \mathrm{MPC}-2$ samples, from 2 to $5 \mathrm{MPC}-2$ samples). In 2014, the exceeded hygienic standards in terms of chemicals content in soil were recorded in the territory of Ufa city for nickel - up to 1.1 MPC, and zinc - up to 2.7 MPC. As for microbiological and parasitological indicators, no exceeded hygienic standards were registered in 2013-2014. The results of soil study in terms of radiological safety did not exceed hygienic standards.

Thus, hygienic assessment of the habitat quality parameters, according to instrumental measurements, showed that a certain danger to the health of participants in summits, guests and residents of the city may be the atmospheric air pollution, and to a lesser extent - the pollution of natural, drinking waters and soils.

Based on the dispersion calculations (for meteorological conditions and meteorological characteristics unfavorable for dispersion, typical for July 2014), specified with the instrumental measurements data, in the places where the official events of SCO and BRICS Summits were held, as well as at the facilities for accommodation, catering, medical services for participants and guests of the summits, there was established:

- of 19 chemical substances discharged in the atmosphere by the stationary and mobile sources in Ufa city, and having an acute noncarcinogenic effects, all 19 substances generate critical concentrations (above 0.001
$\left.\mathrm{MPC}_{\text {single max }}\right)$ in the surface layer of the atmosphere;

- 18 chemicals create the surface concentration of above $0.1 \mathrm{MPC}_{\text {single max; }}$

- the excess of hygienic standards in terms of $\mathrm{MPC}_{\text {single max }}$ is formed in the city area at the analyzed points for such impurities as nitrogen dioxide, nitrogen oxide, carbon (carbon black), carbon oxide, styrene, ethylbenzene, formaldehyde, gasoline (petroleum, low sulfur).

We revealed that out of 81 objects for summits, in the locations of 33 objects, no exceedence in $\mathrm{MPC}_{\text {single max }}$ was forecasted for none of the components, even in the unfavorable meteorological conditions (Dasko-Garden restaurant complex, the RB Ministry of Agriculture Hall of Columns, "White Hall" restaurant, "Parkoviy" hotel complex, Hotel "President Hotel", GC "Azimut Hotel Ufa", etc.).

Part of the summits' objects were located in zones, where $\mathrm{MPC}_{\text {single } \max }$ exceedences were presumable for a number of impurities, in particular, for unfavorable weather conditions, exceedences in carbon (soot) (up to 3.5 $\mathrm{MPC}_{\text {single max }}$ ), formaldehyde (up to 2.7 $\mathrm{MPC}_{\text {single max }}$ ), ethylbenzene (up to $2.4 \mathrm{MPC}_{\text {sin- }}$ gle max), gasoline (petroleum, low-sulfur) (up to 2.1 $\mathrm{MPC}_{\text {single max }}$ ), nitrogen oxide (up to 2.0 $\mathrm{MPC}_{\text {single max }}$ ), carbon oxide (up to $2.0 \mathrm{MPC}_{\text {sin- }}$ gle max), nitrogen dioxide (up to $1.7 \mathrm{MPC}_{\text {single }}$ max), styrene (up to $1.5 \mathrm{MPC}_{\text {single max }}$ ). For meteorological conditions typical for July 2014, the exceedences were forecasted in styrene (up to $1.5 \mathrm{MPC}_{\text {single max }}$ ), carbon (soot) (up to 1.3 $\mathrm{MPC}_{\text {single max }}$ ), nitrogen dioxide (up to 1.2 $\left.\mathrm{MPC}_{\text {single max }}\right)$.

The obtained results of the predictive assessment for the air quality in places, where SCO and BRICS Summits' official events were held, and at the facilities for accommodation, catering, medical services for participants and guests in the summits, showed that the priority pollutants requiring development of measures to reduce emissions and to keep control during the summits in Ufa, in 2015 are: nitrogen dioxide, nitrogen oxide, carbon (carbon black), carbon monoxide, styrene, ethylbenzene, formaldehyde, gasoline. 
Calculations for acute non-carcinogenic risk, expressed by hazard coefficients and indexes, have shown that the city air pollution from the stationary and mobile sources generates unacceptable risks with respect to respiratory and vision organs, and systemic effects both at SCO and BRICS Summits official events locations, as well as at the facilities of accommodation, catering, medical care for participants and guests in the summits. Unacceptable health risks were formed both under the unfavorable meteorological conditions, when dispersal of admixtures in the atmosphere was difficult and under the meteorological conditions typical for July in Ufa (northwest wind at a speed of $2.7 \mathrm{~m} / \mathrm{s}$ ). Fig. 2 shows cartograms reflecting the acute inhalation risk levels' distribution in the territory of Ufa city with respect to respiratory organs under various meteorological conditions.

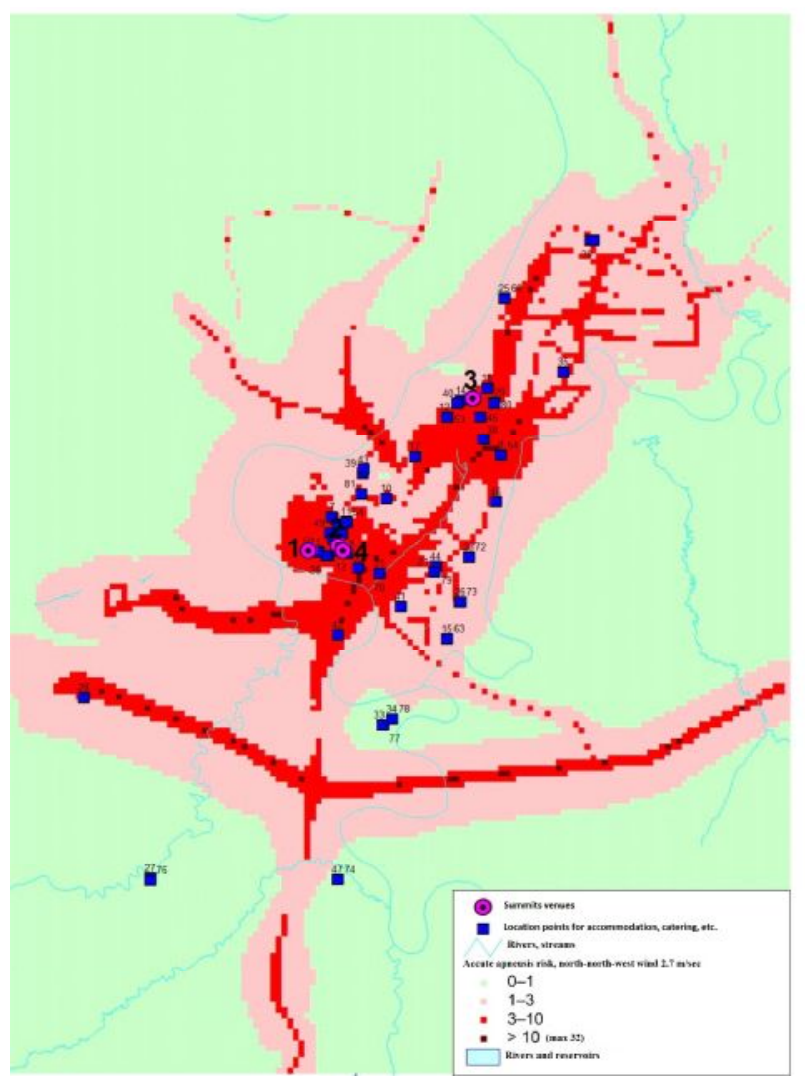

$a$
The highest risk levels (up to $5.7 \mathrm{HI}$, the unfavorable weather conditions in the location of "Agidel" hotel) were forecasted regarding to respiratory organs that is critical, first of all, for the people with allergic diseases, asthma, chronic respiratory disorders. For the organs of vision, under the worst conditions, the unacceptable risk level was generated in 36 points of the Summit facilities' location of up to 3.2 $H I$, including 2 locations of the major events in the summits: the RB State Unitary Enterprise "Congress Hall" (HI 2.3), the state budgetary institution of culture of RB "Bashkir State Theater of Opera and Ballet "(HI 2.1).

An unacceptable risk level of systemic effects was formed at 25 summit objects locations (up to $1.3 \mathrm{HI}$ ) - catering and accommodation facilities for the summits participants and guests.

As for meteorological conditions typical for July 2014, the risk parameters formed had more favorable characteristics.

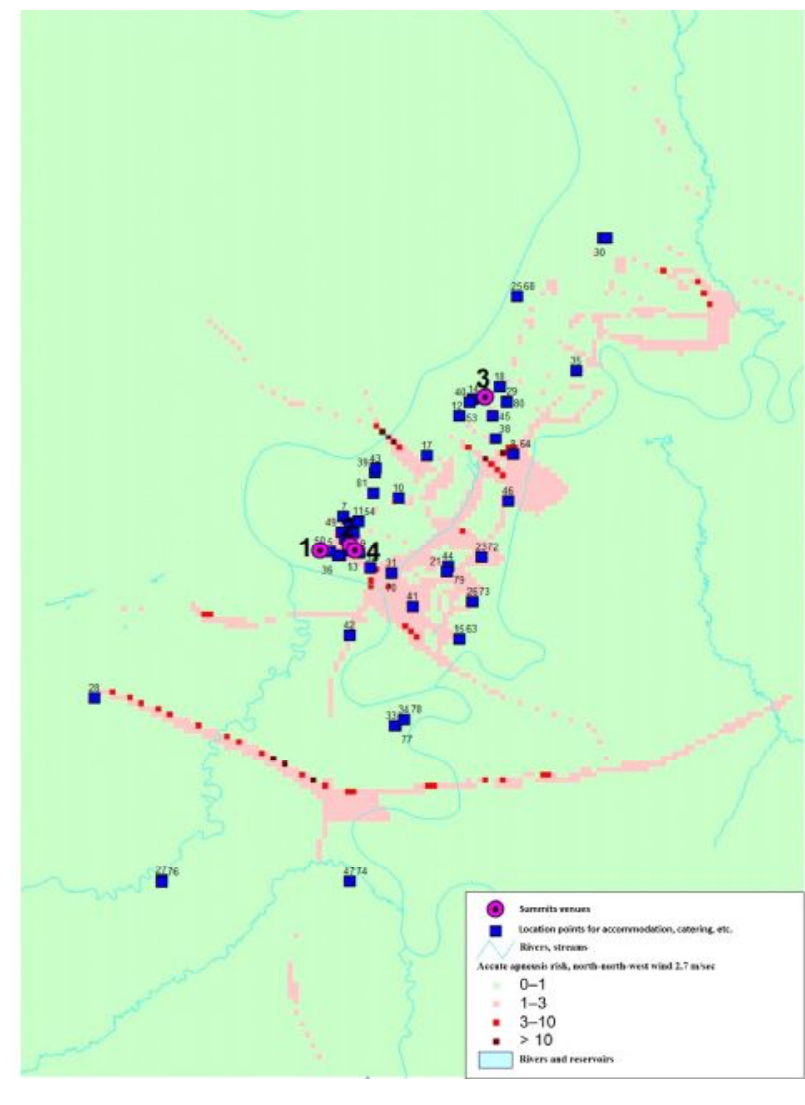

$b$

Fig. 2. Forecasted risk of acute negative effects of atmospheric air pollution on respiratory organs: $a$ - meteorological conditions unfavorable for dispersion; $b$ - typical meteorological characteristics of July 
Nevertheless, an unacceptable risk level for respiratory organs was generated at 57 points of the summit facilities location ( $H I$ up to 2.8), including 2 locations of the Summits major events: SUE RB "Congress Hall" (HI 1.7), the state budgetary institution of culture of RB "Bashkir State Theater of Opera and Ballet" (HI 1.3). The boundary risk level for the visual organs was formed only for the location zone of the "Bashneft" hotel complex (HI 1.05), for systemic effects - for "Panorama" hotel location zone (HI 1.03).

In relation to the rest of the analyzed bodies and target systems, at all location points of the summit facilities, the risk was assessed as acceptable (tolerable).

The identified risks levels of acute inhalation effects were formed by a complex of impurities, but the main contributions were made by no more than 10 priority admixtures out of 16 , considered at the stage of exposure assessment. It was determined that the risk with respect to respiratory organs was formed mainly by: suspended substances, including of finely-dispersed component composition, formaldehyde, nitrogen oxide, nitrogen dioxide, ammonia, hydrogen sulfide, toluene. At the same time, the shares of priority impurities changed depending on the location of the summit facility, but the list of priority pollutants remained unchanged. Thus, the contribution of suspended substances to the hazard index for respiratory organs under unfavorable (worst) weather conditions varied at the different points from 14.9 to $58.7 \%$, of formaldehyde - from 6.8 to $52.7 \%$, nitrogen oxide - from 0.5 to $25.8 \%$, nitrogen dioxide - from 0.96 to $17.0 \%$, ammonia - from 3.0 to $20.7 \%$, toluene - from 0.6 to $11.3 \%$, sulfur dioxide - from 0.2 up to $5.9 \%$, hydrogen sulphide - from 0.43 to $5.6 \%$, hydrochloric acid - from 0.1 to $5.0 \%$, xylene from 0.6 to $2.8 \%$, chloroform - from 0.6 to $2.4 \%$. Other admixtures did not contribute more than $1 \%$.

The contribution of the priority chemical impurities to the formation of hazard index for respiratory organs in weather conditions, typical for July 2014, made for suspended substances: from 26.7 to $79.3 \%$, formaldehyde - from 0.0 to $43.5 \%$, nitrogen oxide - from 0.0 to $23.0 \%$, nitrogen dioxide - from 0.0 to $14.5 \%$, ammonia - from 2.1 to $11.2 \%$, toluene - from 1.1 to $5,2 \%$, sulfur dioxide - from 0.0 to $2.8 \%$, hydrogen sulfide - from 1.3 to $5.4 \%$, hydrochloric acid - from 0.7 to $3.7 \%$, xylene from 0.7 to $4.6 \%$, chloroform - from 0.7 to $4.0 \%$. Other admixtures did not contribute more than $1 \%$.

Thus, the priority chemicals that form acute inhalation risks to the health of the exposed people are the suspended substances (total dusts, including $\mathrm{PM}_{10}, \mathrm{PM}_{2.5}$, formaldehyde, nitrogen oxide, nitrogen dioxide and ammonia. In total, these admixtures in different locations of the summits objects formed from 76 to $94 \%$ of the acute inhalation effects risk for respiratory organs. Irritation of ocular mucosa could be generated under the influence of the higher levels of formaldehyde, ammonia, toluene, xylene, styrene and phenol (the total contribution is $89-99 \%$ of the risk for acute effects on visual organs (ocular mucosa)), i.e. chemical impurities contained in the discharges of a number of the city's industrial enterprises and motor transport emissions.

On the whole, the obtained data made it possible to identify the priority impurities that, contaminating the atmospheric air in Ufa, could be the reason for exceeding the hygienic standards in $\mathrm{MPC}_{\text {single max }}$, and for acute negative effects on the health of the summits participants, guests, and the local population. Nitrogen dioxide, nitrogen oxide, carbon (carbon black), carbon monoxide, styrene, ethylbenzene, formaldehyde, gasoline, suspended matter, ammonia were referred to such impurities.

To set the objectives for risk management, it's been established that the main sources of air pollution due to priority factors in the summits facilities locations are vehicles and small and medium-sized enterprises located in the central part of the city (6 major large industrial enterprises are located in the northeast at a distance of $10-25 \mathrm{~km}$ from the central part of the city, the discharges thereof make about $80 \%$ of all emissions from the stationary sources in Ufa). 


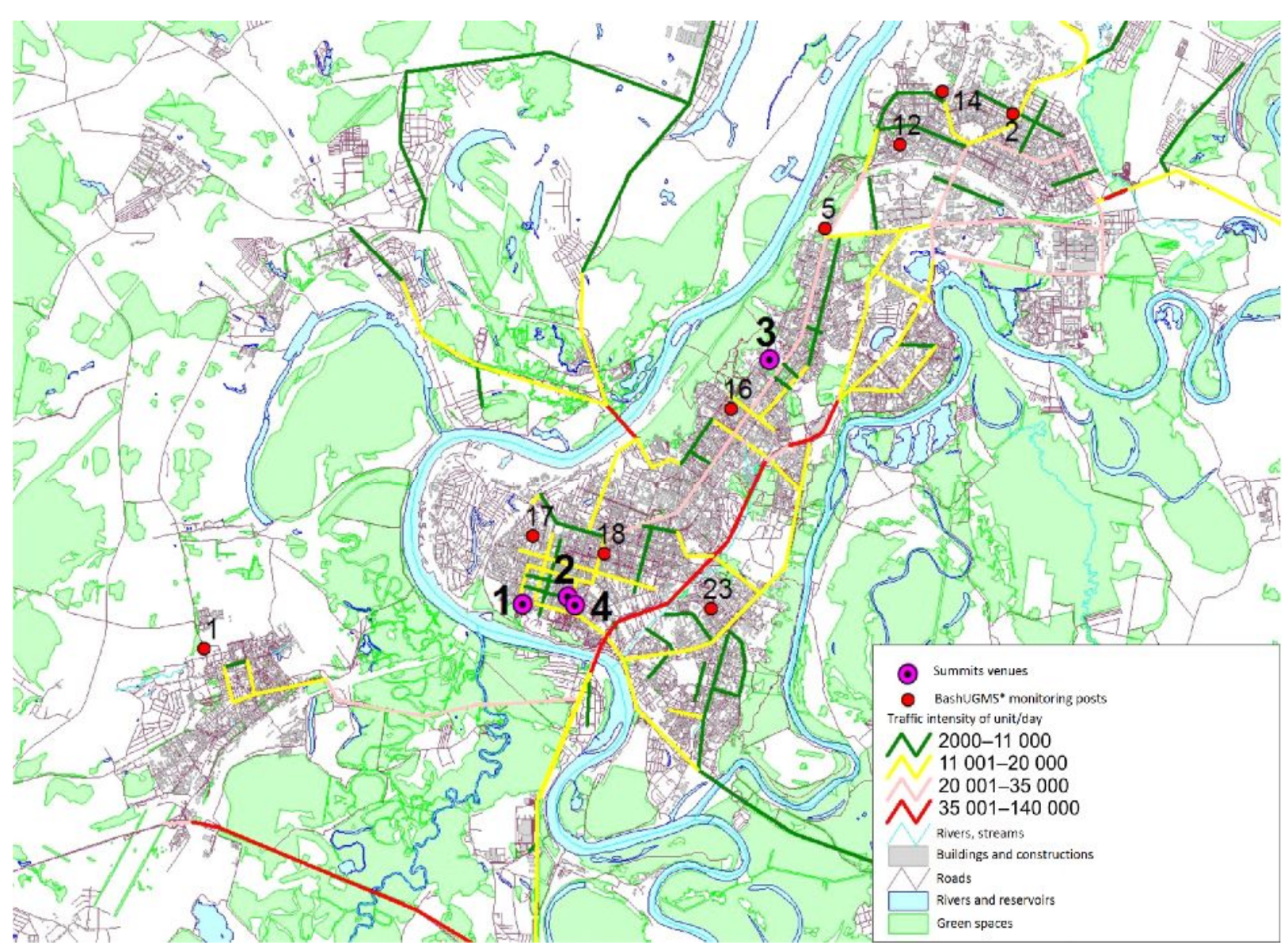

*Bashkir Department for Hydrometeorology and Environmental Monitoring

Fig. 3. Average daily traffic intensity of motor transport in Ufa main highways

Fig. 3 shows the city's main highways with the average daily traffic intensity and their spatial location relative to the main facilities for holding summits in Ufa (2015).

Analyzing water peroral factor at the stage of hazard identification revealed that out of 20 chemical impurities being monitored in the centralized potable water supply system in Ufa, 17 substances have been shown to have the potential to cause adverse effects on human health, including as it relates to gastrointestinal tract, nervous, hematopoietic, reproductive, cardiovascular, immune, endocrine and other body systems.

At the stage of exposure assessment, it's established that the calculated doses for chronic oral intake of the analyzed chemical impurities with drinking water did not exceed the reference levels $(R F D)$ for children and adults at the summits facilities location points. Analysis of the additive unidirectional effect of several drinking water substances on target organs/systems has shown that the chronic impact indexes $\left(\mathrm{THI}_{w o}\right)$ also did not exceed the allowable level for children and adults consuming water in the representativeness zones of monitoring points, and in the summits objects locations (for the latter, $T H I_{w o}$ maximum values were formed for hematopoiesis system at a level of up to $0.17 \mathrm{THI}_{w o}$ ).

Thus, the analysis of health risk for the exposed population, formed by the environmental water peroral factor, showed that chronic non-carcinogenic risk parameters, expressed by hazard coefficients and indexes, did not exceed the permissible level for the adult population for the analysis period. Nitrates, iron, manganese can be referred to as the priority substances (according to the criteria for exceeding hygienic standards); to the relative priorities (substances that form hazard coefficients within the permissible level, but higher 
than other chemical impurities): manganese, benzene, lead, chloroform, mercury.

The soil quality analysis and further expert assessment of the health risk parameters to the population with peroral intake of substances from soil showed that 8 substances out of 9 chemical admixtures monitored in the soils of Ufa city had a proven potential ability to cause adverse non-carcinogenic effects for the health of those exposed, including as it relates to gastrointestinal tract, nervous, hematopoietic, reproductive, immune and other body systems. The calculated coefficients and hazard indexes did not reveal exceedences of the acceptable level for children and adults, both in the representativeness zones of the monitoring points, and at the summits objects location points. At the same time, according to the criteria for maximum permissible concentrations, nickel and zinc should be referred to the priority chemical impurities contained in soils.

In order to minimize risks and prevent health disorders among guests and participants of the summits:

- The priority impurities monitoring programs were developed and further implemented. It is recommended to conduct surveillance studies at the existing observation points of Roshydromet and Rospotrebnadzor for all impurities included in the atmospheric air monitoring programs completing them with instrumental measurements of fine dust fractions $\mathrm{PM}_{10}, \mathrm{PM}_{2.5}$; the drinking water quality control is recommended to be run under a comprehensive sanitary analysis program, the soil - according to the standard programs;

- All sources of potential unacceptable risk were identified, and the enterprises were warned about the need to switch to other operation modes during the periods of unfavorable meteorological conditions. It is recommended to pay special attention to the enterprises located in the central part of the city, and, above all, in close proximity to the places of holding summits, places of catering and accommodation for events guests and participants;
- The necessity to optimize traffic flows for the summits period was proved: redirection of a part of vehicles to other highways; the central part of the city is to be closed for the transit cargo transport; temporary restriction for personal transport to drive on the most stressed sections of the road network for the events duration. There was demonstrated the need to reduce capacity by 4 times of the major, most busy highways: Salavat Yulaev avenue, the bridge across the Belaya River - Gorod Halle, Tsuryupy Street - 50 let Oktayabrya street - Prospect Oktyabrya, Zaki-Validi street - Sochinskaya street;

- The more intensive dust suppression measures are recommended: washing roads using specialized equipment, wetting with watering machines, covering open ground with lawns, etc.

Conclusions. The studies' results showed that in the summits facilities locations, risks of acute negative impacts could be formed under unfavorable weather conditions, which were considerably reduced when the situation was forecasted for the regular July conditions (the month of the events) typical for Ufa. The drinking water and soil in the city did not represent sources of unacceptable health risks. The obtained results allowed for developing a set of activities that ensured minimization of health risks, and safety, from the point of the studied factors in summits holding. The proposed activities can and should be considered not only as a means of achieving a safe living environment for citizens during the period of international events, but also as a means to ensure long-term stable sanitary and epidemiological welfare of Ufa residents.

Implementation of the monitoring program developed, and the proposed sanitary and epidemiological measures, according to the air quality instrumental studies (more than 40 thousand studies for 30 impurities), as well as the drinking water and soils during the SCO and BRICS Summits in Ufa, from 08.07.2015 to 10.07 .2015 , and the arrival and departure days of the summits participants and guests 
allowed for the absence of unacceptable risks of negative effects on the health of Ufa residents, participants and guests of the summits. In that period, there were no cases of acute health problems among the participants and guests of events recorded.

Thus, SCO and BRICS Summits (2015) held demonstrated the effectiveness of meth- odology for assessing non-communicable health risks in preparation and implementation of these activities, including the development and implementation of programs to manage these risks even before the summits' start.

\section{References}

1. Onishchenko G.G., Popova A.Yu., Kuz'kin B.P., [i dr.]. XXII Olimpiiskie zimnie igry i XI Paralimpiiskie zimnie igry 2014 goda v g. Sochi. Obespechenie sanitarno-epidemiologicheskogo blagopoluchiya: monografiya [XXII Winter Olympic Games and XI Paralympic winter games in 2014 in Sochi. Providing sanitary-epidemiologic wellbeing: monograph]. In: G.G. Onishchenko, A. N. Kulichenko eds. Tver, Izdatel'stvo Triada, Publ., 2015, 576 p. (in Russian).

2. Onishchenko G.G., Zaitseva N.V., May I.V. [et al.]. Analiz riska zdorov'yu v strategii gosudarstvennogo sotsial'no-ekonomicheskogo razvitiya: monografiya [Health risk analysis in the strategy of state social and economical development]. In: G.G. Onishchenko, N.V. Zaitseva. Perm, Izd-vo Permskogo natsional'nogo issledovatel'skogo politekhnicheskogo universiteta Publ., 2014, 738 p. (in Russian).

3. Global'nye massovye meropriyatiya: ikh znachenie i vozmozhnosti dlya obespecheniya bezopasnosti zdorov'ya v mire: Doklad Sekretariata [Global mass events: their significance and possibilities to provide health safety in the world: Secretariat Report]. Vsemirnaya organizatsiya zdravookhraneniya, 2011, 8 p. Available at: http: //apps.who.int/iris/bitstream/10665/25910/1/B130_17-ru.pdf (23.03.2016) (in Russian).

4. Zaitseva N.V., May I.V., Kleyn S.V. Optimizatsiya programm nablyudeniya za kachestvom atmosfernogo vozdukha selitebnykh territorii $\mathrm{v}$ sisteme sotsial'no-gigienicheskogo monitoringa na baze prostranstvennogo analiza i otsenki riska dlya zdorov'ya naseleniya [Optimization of programs for monitoring air quality on areas aimed for development in social-hygienic monitoring system on the basis of spatial analysis and population health risk assessment]. Permskii meditsinskii zhurnal, 2010, vol. 27, no. 2, pp. 130-138 (in Russian).

5. Mezhdunarodnye mediko-sanitarnye pravila [International Health Regulations (2005)]. Vsemirnaya organizatsiya zdravookhraneniya, 2008,90 p. Available at: http: //www.who.int/ihr/9789241596664/ru/ (22.02.2017) (in Russian).

6. Imamov A.A., Balabanova L.A., Zamalieva M.A., Radchenko O.R. O planirovanii laboratornykh issledovanii $\mathrm{v}$ tselyakh obespecheniya sanitarno-epidemiologicheskogo blagopoluchiya pri provedenii massovykh meropriyatii [On planning of laboratory researches for ensuring sanitary and epidemiologic wellbeing during carrying out mass actions]. Vestnik Rossiiskoi voenno-meditsinskoi akademii, 2015, vol. 49, no. 1, pp. 185-188 (in Russian).

7. Balakhonov S.V., Chesnokova M.V., Andaev E.I., Kosilko S.A. i dr. Obespechenie sanitarnoepidemiologicheskogo blagopoluchiya $\mathrm{v}$ period podgotovki i provedeniya sammita ATES-2012: monografiya [Providing sanitary-epidemiologic wellbeing during preparation to APEC-2012 Summit and the Summit itself: monograph]. In: G.G. Onishchenko ed. Novosibirsk, Izd-vo Nauka-Tsentr Publ., 2013, 419 p. (in Russian).

8. Vekovshinina S.A., Kleyn S.V., Balashov S.Yu., Nikiforova N.V., Ukhabov V.M. Olimpiada2014 v Sochi: vybor prioritetnykh pokazatelei i razrabotka mer po upravleniyu riskami zdorov'yu ot vozdeistviya khimicheskikh veshchestv [Olympic games 2014 in Sochi: selection of priority indicators and measures of management of health risk caused by chemicals]. Zdorov'e sem'i-21 vek, 2015, no. 3, pp. 9-25 (in Russian). 
9. Olimpiiskaya Khartiya (v deistvii s 9 sentyabrya 2013 g.) [Olympic Charter (came to force on September 9, 2013)]. Mezhdunarodnyi olimpiiskii komitet, 2010. 47 p. Available at: http: //olympic.ru/upload/documents/about-committee/charter/charter_09_09_2013.pdf (23.01.2017) (in Russian).

10. Patyashina M.A., Balabanova L.A. Problemy obespecheniya sanitarno-epidemiologicheskogo blagopoluchiya massovykh meropriyatii $\mathrm{s}$ mezhdunarodnym uchastiem $\mathrm{v}$ sovremennykh usloviyakh [Current problems of surveying sanitary and epidemiological well-being at public events with international participation]. Kazanskii meditsinskii zhurnal, 2015, vol. 96, no. 1, pp. 90-95 (in Russian).

11. Zaitseva N.V., May I.V., Kleyn S.V., Vekovshinina S.A., Balashov S.Yu. Prakticheskii opyt otsenki i upravleniya neinfektsionnymi riskami dlya zdorov'ya pri podgotovke massovykh sportivnykh meropriyatii (na primere Vsemirnoi letnei Universiady - 2013 v Kazani i Olimpiiskikh zimnikh igr $2014 \mathrm{v}$ Sochi) [Practical experience in the assessment and management of non- infectious health risks during the preparation of the mass sports events (using the example of the 2013 summer Universiade in Kazan and the 2014 Winter Olympics in Sochi)]. Zdorov'e naseleniya i sreda obitaniya, 2015, vol. 273, no. 12, pp. 4-7 (in Russian).

12. Rukovodstvo po ocenke riska dlja zdorov'ja naselenija pri vozdejstvii himicheskih veshhestv, zagrjaznjajushhih okruzhajushhuju sredu R 2.1.10.1920-04 [Guide to health risk assessment when exposed to chemicals polluting the environment 2.1.10.1920-04]. Moscow, Federal'nyj centr Gossanjepidnadzora Minzdrava Rossii publ., 2004, 143 p. (in Russian).

13. Onishchenko G.G., Kutyrev V.V., Toporkov V.P., Karnaukhov I.G., Kulichenko A.N., Balakhonov S.V., Toporkov A.V Sovremennye mobil'nye protivoepidemicheskie kompleksy pri preduprezhdenii i operativnom reagirovanii na chrezvychainye situatsii biologicheskogo kharaktera [State-of-the-art mobile anti-epidemic complexes in the prevention of and response to emergency situations of biological character]. Infektsionnye bolezni: novosti, mneniya, obuchenie, 2016, vol. 14, no. 1, pp. 93-101 (in Russian).

14. Udovichenko S.K., Toporkov A.V., Toporkov V.P. Metodologicheskie aspekty otsenki epidemiologicheskikh riskov pri provedenii massovykh meropriyatii s mezhdunarodnym uchastiem [Methodological aspects of epidemiologic risks assessment during mass events with international participation]. Innovatsionnye tekhnologii $v$ protivoepidemicheskoi zashchite naseleniya: Materialy Vserossiiskoi nauchno-prakticheskoi konferentsii, posvyashchennoi 95-letiyu Nizhegorodskii NII epidemiologii $i$ mikrobiologiii im. akademika I.N. Blokhinoi [Innovative technologies in anti-epidemic protection of the population. Materials of the Russian theoretical and practical conference devoted to the 95-the anniversary of I.N. Blokhina's Nizhniy Novgorod Scientific Research Institute for epidemiology and microbiology], 2014, pp. 22-25 (in Russian).

15. Dapeng J., Ljungqvist A., Troedsson H. The health Legacy of the 2008 Beijing Olympic Games. Successes and Recommendations. World Health Organization, 2008, $191 \mathrm{p}$.

16. Enock K. E., Jacobs J. The Olympic and Paralympics Games 2012: literature review of the logistical planning Operational challenges for public health. Public Health, 2008, vol. 122, no. 11, pp. 1229-1238. DOI: 10.1016/j.puhe.2008.04.016.

17. Environmental Health Risk Assessment: Guidelines for assessing human health risks from environmental hazards. Available at: http: //www.eh.org.au/resources/knowledge-centre/enhealth-nationaldocuments (22.07.2016).

18. Shafi S., Booy R., Haworth E. [et al.]. Hajj: health lessonsfor mass gatherings. Public Health, 2008, vol. 1, no. 1, pp. 27-32.

19. London 2012 Olympic and Paralympic Games: Health Protection Agency Testing and Exercising Summary Report, 2013, 7 p. Available at: https: //www.gov.uk/government/uploads/system/uploads/attachment data/ file/398939/1_London_2012_HPA_summary_testing_and_exercising_report.pdf (22.04.2017).

20. Steffen R. Mass gatherings health risks and preventivestrategies. Ther. Vmsch, 2013, vol. 70, no. 6 , pp. 350-352. 
Kleyn S.V., Balashov S.Yu., Stepanov E.G., Davletnurov N.Kh. Trial hygienic assessment and minimizing environmental health risks during leaders council meeting of shanghai cooperation organization countries and meeting of leaders and government heads of BRICS countries held in Ufa. Health Risk Analysis, 2017, no. 2, pp. 68-81. DOI: 10.21668/health.risk/2017.2.08.eng

Received: 25.01.2017

Accepted: 06.03.2017

Published: 30.06 .2017 